\title{
GAMBARAN INFESTASI VEKTOR PADA KAPAL PENUMPANG DAN KAPAL BARANG YANG SANDAR DI PELABUHAN BAU-BAU
}

\author{
Adi Supryatno ${ }^{1}$, Sischa Andriani Alimin ${ }^{1}$, Tria Saras Pertiwi ${ }^{2}$ \\ ${ }^{1}$ Universitas Banten Jaya, J1 Syech Nawawi Albantani Serang, Banten, Indonesia \\ ${ }^{2}$ Universitas Esa Unggul, Jl. Arjuna Utara, Jakarta, Indonesia
}

\begin{abstract}
High transportation needs can cause health problems, such as vector infestation. Vector infestation is most likely caused by the behavior of the crew, the age of the ship, the number of passengers, the cleanliness of the ship, and resistance to continuous use of pesticides. The purpose of this study was to describe the location of vector infestations on passenger ships and cargo ships that dock at Baubau port. This type of research is a quantitative descriptive using a cross sectional study design. The object of this research is the ships that docked at the Bau-bau port in December 2017 as many as 12 passenger ships and 12 cargo ships. Insect prevalence was measured by calculating the percentage of the number of insects caught. The results of the research were processed descriptively to see a description of the location of vector infestations on passenger ships and cargo ships that docked at Bau-bau Harbor by looking at the characteristics of the ship based on the type of ship and the age of the ship. The results obtained that cockroaches are the vectors with the highest infestation on ships as many as 10 on passenger ships and 11 on cargo ships. The average age of ships that dock at Baubau port is quite old. Vessels > 7 years old have the most vector infestations and cockroaches are one of the most numerous types of vectors.
\end{abstract}

Keywords: Vector Infestation, Passenger Ship, Freight Ship.

\begin{abstract}
ABSTRAK
Kebutuhan transportasi yang tinggi dapat menimbulkan masalah kesehatan, seperti infestasi vektor. Infestasi vektor kemungkinan besar disebabkan oleh perilaku ABK, usia kapal, jumlah penumpang, kebersihan kapal, dan ketahanan terhadap penggunaan pestisida secara terus menerus. Tujuan penelitian ini adalah untuk mengetahui gambaran lokasi infestasi vektor pada kapal penumpang dan kapal barang yang sandar di pelabuhan Baubau. Jenis penelitian ini merupakan deskriptif kuantitatif dengan menggunakan desain cross sectional study. Objek penelitian ini yaitu kapal yang bersandar di pelabuhan Bau-bau pada bulan Desember 2017 sebanyak 12 kapal penumpang dan 12 kapal barang. Prevalensi serangga diukur dengan menghitung persentasi jumlah serangga yang tertangkap. Hasil penelitian diolah secara deskriptif untuk melihat gambaran lokasi infestasi Vektor pada kapal penumpang dan kapal barang yang bersandar di Pelabuhan Bau-bau dengan melihat karakteristik kapal berdasarkan jenis kapal dan umur kapal. Hasil penelitian diperoleh yaitu Lipas merupakan vektor yang paling tinggi menginfestasi pada kapal sebanyak 10 pada kapal penumpang dan 11 pada kapal barang. Rata-rata umur kapal yang sandar di pelabuhan Baubau sudah cukup tua. Kapal yang berumur $>7$ tahun memiliki infestasi vektor terbanyak dan lipas merupakan slah satu jenis vektor yang paling banyak jumlahnya.
\end{abstract}

Kata Kunci: Infestasi Vektor, Kapal Penumpang, Kapal barang. 


\section{INTRODUCTION}

Indonesia merupakan negara kepulauan yang memiliki berbagai moda transportasi, salah satunya laut sarana transportasi. Sarana transportasi merupakan tempat atau alat yang dipergunakan oleh masyarakat umum untuk melakukan kegiatannya, oleh karena itu perlu dikelola demi kelangsungan hidup dan penghidupannya untuk mencapai keadaan sejahtera dari badan, jiwa dan sosial, yang memungkinkan penggunanya hidup dan bekerja dengan produktif secara sosial ekonomis. Misalnya pada sarana transportasi laut (Mandagie, 2011)

Transportasi laut merupakan tempat yang sering digunakan masyarakat untuk mengadakan perjalanan. Sarana transportasi laut yang tidak dirawat dengan baik dapat menimbulkan masalah kesehatan, satu diantaranya perkembangan vektor penyakit seperti lipas, nyamuk dan lalat. Penularan penyakit ke manusia melalui vektor berupa serangga disebut Vector borne deseases. Terdapat ratusan juta penyakit yang ditularkan oleh serangga dan hewan pengerat setiap tahun. Penyakit yang ditularkan melalui vektor merupakan ancaman besar bagi kesehatan masyarakat global, termasuk malaria, demam berdarah, leptospirosis, dan tifus. Penyakit yang ditularkan oleh hewan vektor menyumbang lebih dari $17 \%$ dari semua penyakit menular di dunia, menyebabkan lebih dari 700.000 kematian setiap tahun. Lebih dari 3,9 miliar orang di 128 negara berisiko terkena demam berdarah, dengan 96 juta kasus setiap tahun (Sari, 2020). Penyakit-penyakit tersebut dapat menyebabkan kejadian luar biasa (KLB) dan memerlukan respon dan penanganan yang cepat antar negara, yang disebut sebagai "Internationally Important Public Health Emergencies (PHEIC)" dalam International Health Regulations (IHR) 2005 (A. Soghaier, M.I. Saeed, \& K. Zaman, 2015).

Menurut peraturan Menteri Kesehatan Republik Indonesia No. 374/MENKES/PER/III/2010 tentang pengendalian vektor. Pengendalian vektor adalah segala kegiatan atau tindakan yang bertujuan untuk mengurangi jumlah vektor sebanyak-banyaknya sehingga keberadaannya tidak lagi memiliki risiko penyebaran penyakit tular vektor, sehingga penyebaran penyakit tular vektor dapat dicegah (Kemenkes RI, 2010).

Sarana transfortasi laut seperti kapal penumpang merupakan alat transfortasi yang sering digunakan masyarakat untuk kebutuhan sehari-hari bagi penduduk untuk berpindah dari satu tempat ke tempat lain. Kebutuhan transportasi yang tinggi dapat menimbulkan masalah kesehatan, seperti infestasi vektor. Infestasi vektor kemungkinan besar disebabkan oleh perilaku ABK, usia kapal, jumlah penumpang, kebersihan kapal, dan ketahanan terhadap penggunaan pestisida secara terus menerus. Hasil survei yang dilakukan oleh Oldenburg dan Bauer (2008) menunjukan bahwa pada tahun 2005, 6 kapal kontainer yang sandar di pelabuhan 
Hamburg berumur lebih dari 7 tahun ditemukan vektor kecoa. Mouchtouri (2008) juga menjelaskan bahwa 11 kapal Fery yang datang di pelabuhan Yunai ditemukan berbagai macam jenis serangga seperti Blatella germanica, Musca domestica, Drosophilla spp, Bedbugs, pinjal, semut, kumbang, dan kupu-kupu yang tersebar di ruang utama, ruang dapur, bar, ruang makan, dan gudang makanan.

Menurut WHO lebih dari 100 outbreak penyakit infeksi memiliki hubungan dengan kapal laut. laporan CDC pada 2004-2017 menunjukkan sebanyak 239 kapal pesiar yang tiba di Pelabuhan U.S mengalami outbreak gastrointestinal, lebih dari 10.000 penumpang dan crew kapal mengalami gejala muntah-muntah dan diare (Fitriana, Retno, Martini, \& Praba, 2017).

Pelabuhan Bau-bau merupakan pelabuhan transit yang menghubungkan pulau-pulau bagian timur dan barat Indonesia. Pelabuhan tersebut terletak di Kota Baubau, Provinsi Sulawesi Tenggara. Mengingat aktifitas kapal penumpang di Pelabuhan Bau-bau sangat aktif, sehingga memungkinkan terjadinya perkembagan vektor. Oleh karena itu, perlu dilakukan penelitian tentang gambaran lokasi infestasi vektor pada kapal penumpang dan kapal barang yang sandar di pelabuhan Bau-bau.

\section{METHOD}

Jenis penelitian ini merupakan deskriptif kuantitatif dengan menggunakan desain cross sectional study. Objek penelitian ini yaitu kapal yang bersandar di pelabuhan Bau-bau pada bulan Desember 2017 sebanyak 12 kapal penumpang dan 12 kapal barang. Pertimbangan menggunakan metode ini adalah jenis kapal yang datang di pelabuhan Baubau tidak terjadwal. Penangkapan serangga di setiap lokasi kapal dengan menggunakan flusing agent/spray untuk lipas, sweeping net untuk menangkap lalat, aspirator dan aerosol untuk penangkapan nyamuk, pinset untuk penangkapan semut, dan space spray untuk penangkapan bedbugs. Alat-alat tersebut diaplikasikan di tiap ruangan dalam kapal selama 30 menit. Prevalensi serangga diukur dengan menghitung persentasi jumlah serangga yang tertangkap. Hasil penelitian diolah secara deskriptif untuk melihat gambaran lokasi infestasi Vektor pada kapal penumpang dan kapal barang yang bersandar di Pelabuhan Bau-bau dengan melihat karakteristik kapal berdasarkan jenis kapal dan umur kapal.

\section{RESULTS AND DISCUSSION}

Karakteristik kapal sangat berkaitan erat dengan infestasi vektor di atas kapal. Karakteristik yang diamati dalam penelitian ini, yaitu: jenis kapal dan konstruksi umur kapal. Jenis kapal yang masuk di pelabuhan Baubau di antaranya kapal barang dan kapal penumpang 
yaitu sebesar 24 kapal dengan bendera Indonesia. Jumlah infestasi vektor pada kapal penumpang di antaranya lipas $0,47 \%$, Nyamuk $0,5 \%$, Jentik 0,75 , dan Semut 0,5 . Kemudian kapal barang lipas 0,92\%, Nyamuk 0,5\%, Jentik 0,25\%, Magot 1\%, Semut $0.4 \%$ dan Bedbugs $0,6 \%$.

Lipas merupakan vektor yang paling tinggi menginfestasi pada kedua kapal hal ini sejalan dengan penelitian yang lakukan oleh Nurbayani et al,. (2021) terdapat tanda keberadaan kecoa $(33,3 \%)$. Hal ini dapat menyebabkan berbagai gangguan pada penumpang terutama ketidaknyamanan selama berada di kamar penumpang dan beresiko terjadi penularan penyakit. Penelitian lainnya oleh Mouchtouri et al. (2008) ditemukan sebanyak 52,3\% dari kapal memiliki infestasi kecoa dibanditng jenis vektor lainnya dengan lokasi yang terinfestasi termasuk dapur, bar, dapur, makanan gudang, tempat sampah, dan ruang makan. Galai adalah area kapal yang paling penuh (khususnya di bawah lemari es). Penelitian yang serupa juga dilakukan oleh Harahap (2016) sebanyak 40\% kapal motor yang memiliki tingkat resiko ganguan kesehatan tinggi, sebesar 91,67\% ditemukan adanya kecoa dengan kategori tinggi atau padat. Selain itu, kecoak telah diakui sebagai penyebab utama morbiditas asma dan beberapa produksi kecoa alergen telah diidentifikasi dan dikarakterisasi.

Sebuah penelitian yang dilakukan di Hamburg, Jerman, menunjukkan bahwa Pelaut yang peka terhadap kecoa sering menunjukkan gejala gangguan fungsi paru obstruktif, yang merupakan bukti risiko pernapasan kerja karena paparan kecoak di kapal (Oldenburg \& Baur, 2006). Kecoa mempunyai perilaku mengeluarkan makanan yang baru dikunyah atau memuntahkan makanan dari lambungnya, karena sifat inilah mereka mudah menularkan penyakit pada manusia. Tinja kecoa dilaporkan mengandung asam kynurenat, asam xanturenat, dan 8- hydroxyquinaldat acids senyawa ini dilaporkan bersifat mutagenik dan karsinogenik (Putri, Joko, \& YDN, 2017)

Menurut Fitriana, Retno, Martini, \& Praba (2017) kecoa dapat berperan sebagai vektor mekanik bagi beberapa mikroorganisme seperti Streptococcus, Salmonella sp, Shigella sp, Campylobacter sp, Pseudomonas aeruginosa, Mycobacterium leprae, dan Klebsiella pneumoniae sehingga mereka berperan dalam penyebaran penyakit disentri, diare, kolera, virus Hepatitis A, polio pada anak-anak, dan sebagai inang perantara bagi beberapa spesies cacing. Oleh karenanya perlu pengendalian keberadaan vector khususnya pada kapal melihat kelompok umur pada kapal baik kapal penumpang dan kapal barang bisa dari semua kalangan baik yang muda maupun tua. Keberadaan vektor pada kapal dapat dihilangkan dengan 
memperbaiki kondisi higiene sanitasi kapal seperti sanitasi ruangan, higiene sanitasi makanan minuman, dan pengelolaan limbah. Pengelolaan sampah yang tidak baik dapat menimbulkan bau yang tidak sedap dan dapat menyebabkan perkembangan vector seperti kecoa (Mandagie, 2011).

Tabel 1. Distribusi Lokasi Infestasi Vektor pada Kapal Penumpang dan Kapal Barang yang Sandar di Pelabuhan Baubau

\begin{tabular}{llllllll}
\hline \multirow{2}{*}{$\begin{array}{l}\text { kapakteristik } \\
\text { Jenis kapal }\end{array}$} & \multicolumn{7}{l}{ Jumlah Kapal per jenis Vektor $\left(\sum\right.$ kapal/\%) } \\
\cline { 2 - 7 } & Lipas & Nyamuk & Jentik & lalat & Magot & Semut & Bedbugs \\
\hline KP & $10(0.47)$ & $4(0.5)$ & $3(0.75)$ & $7(0.58)$ & $0(0)$ & $10(0.5)$ & $0(0)$ \\
\hline KB & $11(0.92)$ & $4(0.5)$ & $1(0.25)$ & $5(0.42)$ & $2(1)$ & $8(0.4)$ & $2(0.6)$ \\
\hline Jumlah & $\mathbf{2 1}$ & $\mathbf{8}$ & $\mathbf{4}$ & $\mathbf{1 2}$ & $\mathbf{2}$ & $\mathbf{1 8}$ & $\mathbf{3}$ \\
\hline Umur & & & & & & & \\
\hline$<4$ tahun & $1(0.04)$ & $0(0)$ & $0(0)$ & $1(0.08)$ & $0(0)$ & $1(0.05)$ & $0(0)$ \\
\hline 4-7 tahun & $3(0.14)$ & $3(0.375)$ & $2(0.5)$ & $1(0.08)$ & $0(0)$ & $3(0.16)$ & $0(0)$ \\
\hline$>7$ tahun & $17(0.81)$ & $5(0.625)$ & $2(0.5)$ & $10(0.8)$ & $2(1)$ & $14(0.7)$ & $3(1)$ \\
\hline Jumlah & $\mathbf{2 1}$ & $\mathbf{8}$ & $\mathbf{4}$ & $\mathbf{1 2}$ & $\mathbf{2}$ & $\mathbf{1 8}$ & $\mathbf{3}$ \\
\hline
\end{tabular}

Umur kapal juga sangat menunjang adanya infestasi vektor. Rata-rata umur kapal yang sandar di pelabuhan Baubau sudah cukup tua, yaitu berkisar $<4$ tahun, $4-7$ tahun dan $>7$ tahun. Kapal yang berumur $<4$ tahun memiliki tingkat infestasi vektor terendah sebanyak (3 kapal, $0.13 \%$ ) di antaranya lipas, nyamuk dan semut. Berbeda dengan kapal yang berumur 47 tahun dan $>7$ tahun memiliki infestasi terbanyak. Kapal yang berumur $>7$ tahun memiliki infestasi vektor terbanyak yaitu lipas. Hal ini sejalan dengan penelitian oleh Oldenburg \& Baur (2008) bahwa rata-rata usia kapal yang sangat tua memiliki infestasi lipas terbanyak dengan usia kapal 35 tahun dengan 6 kapal yang dipenuhi kecoa selama 12 bulan sebelumnya. Hanya kapal yang lebih besar dari 10.000 GRT yang terinfestasi. Infestasi kecoa terdeteksi pada 4 kapal kontainer, 1 kapal kargo, dan 1 kapal curah. Dari kapal yang terinfeksi, 4 (66,7\%) secara teratur tinggal di daerah tropis.

\section{CONCLUSION}

Jenis kapal yang masuk di pelabuhan Baubau di antaranya kapal barang dan kapal penumpang yaitu sebesar 24 kapal dengan bendera Indonesia. Jumlah infestasi vektor pada 
kapal penumpang yang ditemukan di antaranya lipas $0,47 \%$, Nyamuk $0,5 \%$, Jentik 0,75 , dan Semut 0,5. Kemudian kapal barang lipas 0,92\%, Nyamuk 0,5\%, Jentik 0,25\%, Magot 1\%, Semut $0.4 \%$ dan Bedbugs 0,6\%. Lipas merupakan vektor yang paling tinggi menginfestasi pada kedua kapal. Umur kapal juga sangat menunjang adanya infestasi vektor. Rata-rata umur kapal yang sandar di pelabuhan Baubau sudah cukup tua, yaitu berkisar $<4$ tahun , 4-7 tahun dan $>7$ tahun. Kapal yang berumur $<4$ tahun memiliki tingkat infestasi vektor terendah sebanyak (3 kapal, 0.13\%) di antaranya lipas, nyamuk dan semut. Berbeda dengan kapal yang berumur 4-7 tahun dan $>7$ tahun memiliki infestasi terbanyak.

\section{ACKNOWLEDGMENTS}

Penulis ingin menyampaikan terima kasih yang tulus kepada Universitas Banten Jaya dan Universitas Esa Unggul Jakarta, Indonesia, serta terima kasih khusus untuk semua data kolektor, pengawas, dan peserta studi.

\section{REFERENCES}

A. Soghaier, M., M.I. Saeed, K., \& K. Zaman, K. (2015). Public Health Emergency of International Concern (PHEIC) has Declared Twice in 2014; Polio and Ebola at the Top. AIMS Public Health, 2(2), 218-222. https://doi.org/10.3934/publichealth.2015.2.218

Fitriana, D., Retno, H., Martini, \& Praba, G. (2017). BAKTERI KONTAMINAN Salmonella sp. PADA KECOA (Blattidae) DI KAPAL DOMESTIK YANG BERSANDAR DI PELABUHAN PANGKALBALAM KEPULAUAN BANGKA BELITUNG. Jurnal Kesehatan Masyarakat (e-Journal), 5(4), 554-559.

Harahap, A. (2016). Faktor yang berhubungan dengan kepadatan kecoa dan keberadaan tikus pada Kapal Motor yang sandar di Pelabuhan Tanjung Perak Surabaya. J Kesling, 8(2), $172-183$.

Kemenkes RI. PERATURAN MENTERI KESEHATAN REPUBLIK INDONESIA TENTANG PENGENDALIAN VEKTOR. , Pengendalian Vektor § (2010).

Mandagie, H. Y. (2011). Tinjauan Fasilitas Sanitasi Kapal Motor Ratu Maria Jurusan ManadoTalaud Tahun 2010. Jurnal Kesehatan Lingkungan, 1(1), 28-38. Retrieved from http://ejurnal.poltekkesmanado.ac.id/index.php/JKL/article/view/56

Mouchtouri, V. A., Anagnostopoulou, R., Samanidou-Voyadjoglou, A., Theodoridou, K., Hatzoglou, C., Kremastinou, J., \& Hadjichristodoulou, C. (2008). Surveillance study of 
vector species on board passenger ships, risk factors related to infestations. BMC Public Health, 8, 1-8. https://doi.org/10.1186/1471-2458-8-100

Nurbayani, N., Husna, H., Syam, B., \& ... (2021). Hubungan Kondisi Sanitasi dengan Keberadaan Kecoa pada Kapal Penumpang di Pelabuhan Ulee Lheue Kota Banda Aceh. Jurnal Serambi ..., 8(8), 1-11. Retrieved from http://www.ojs.serambimekkah.ac.id/serambi-akademika/article/view/2796

Oldenburg, M., \& Baur, X. (2006). Lung function of cockroach sensitized seamen. Eur Respir $J, 28(50), 242-243$.

Oldenburg, M., \& Baur, X. (2008). Cockroach infestation on seagoing ships. Archives of Environmental and Occupational Health, 63(1), 41-46. https://doi.org/10.3200/AEOH.63.1.41-46

Putri, I. ., Joko, T., \& YDN, A. (2017). Evaluasi sanitasi dan keberadaan vektor pada kapal barang dan kapal penumpang di Pelabuhan Tanjung Emas Semarang. J Kesehatan Masyarakat, 5(5), 677-689.

Sari, V. A. (2020). Gambaran Keberadaan Vektor Penyakit Dan Binatang Pengganggu Di Bagian Instalasi Gizi Dan Bangsal Rumah Sakit Tipe C Kota Surakarta. 